\author{
Marcin Salamaga \\ Katedra Statystyki \\ Uniwersytet Ekonomiczny w Krakowie
}

\title{
Wykorzystanie metody bootstrapowej do badania zyskowności wybranych strategii inwestycyjnych na Giełdzie Papierów Wartościowych w Warszawie
}

\section{Streszczenie}

Celem artykułu jest przedstawienie wybranych strategii inwestycyjnych na polskim rynku kapitałowym wraz z oceną ich zyskowności. Istotą stosowanych strategii jest określenie momentów, w których generowane są sygnały kupna lub sprzedaży walorów notowanych na GPW w Warszawie. W tym celu wykorzystano m.in. różne systemy średnich kroczących obliczonych dla głównych indeksów giełdowych w Polsce. Aby ocenić efektywność stosowanych strategii, przeprowadzono klasyczne testy istotności różnic średnich stóp zwrotu oraz zastosowano analizę symulacji metodą bootstrapową.

Słowa kluczowe: analiza techniczna, średnia krocząca, metoda bootstrapowa, model GARCH.

\section{Wprowadzenie}

Aktywny inwestor, którego celem jest maksymalizacja dochodu z inwestycji w krótkim lub w średnim horyzoncie czasowym, postępuje najczęściej zgodnie z zasadą „kupuj tanio i sprzedaj drogo”. Wymaga to stosowania zasad inwestowania 
cyklicznego, a także dobrej znajomości rynku inwestycyjnego. Część inwestorów stosujących narzędzia inwestowania cyklicznego korzysta z analizy technicznej rynku finansowego. Jej celem jest przewidywanie punktów zwrotnych trendu cen akcji (indeksów giełdowych), co umożliwia inwestorowi zajęcie pozycji inwestycyjnej adekwatnej do przewidywanych zmian cen akcji (indeksów). Pomimo istniejącej krytyki narzędzi analizy technicznej wiele badań empirycznych potwierdza, że jej stosowanie pozwala na zrealizowanie wyższych stóp zwrotu w porównaniu ze strategią inwestycyjną „kup i trzymaj” (por. [Pring 1998, Brock, Lakonishok i LeBaron 1992, Isakov i Hollistein 1999]). Badania te stały się inspiracją do podjęcia podobnej tematyki w odniesieniu do polskiego rynku kapitałowego.

Celem artykułu jest ocena zyskowności wybranych strategii inwestowania cyklicznego na przykładzie trzech indeksów giełdowych: WIG20, mWIG40 i sWIG80. W pracy wykorzystano popularne wskaźniki analizy technicznej: średnie kroczące wraz z dodatkowymi metodami filtracji sygnałów kupna i sprzedaży (por. [Czekała 1997, Murphy 1999]). Aby ocenić efektywność stosowanych strategii, zbadano statystyczną istotność różnic warunkowych stóp zwrotu z indeksu giełdowego dla strategii opartych na kupnie, sprzedaży, strategii mieszanej i średniej stopy zwrotu obliczonej dla strategii „kup i trzymaj”. W celu potwierdzenia statystycznej istotności różnic średnich stóp zwrotu ze strategii opartych na inwestowaniu cyklicznym oraz średniej stopy zwrotu ze strategii „kup i trzymaj" wykorzystano replikowane stopy zwrotu indeksu giełdowego wygenerowane z modelu błądzenia losowego z dryfem, modelu autoregresji AR(1) oraz modelu AR(1) z efektem GARCH (1,1). W badaniu uwzględniono dane z indeksów giełdowych WIG20, mWIG40 i sWIG80 według cen zamknięcia sesji giełdowych z okresu 31.12.1997-8.05.2012 .

\section{Metoda badania}

Do wykrywania sygnałów kupna bądź sprzedaży walorów giełdowych zastosowano popularną w analizie technicznej metodę prostej średniej kroczącej. Wartości średniej ruchomej k-okresowej można obliczyć według wzoru [Gencay 1996, s. 165]:

$$
m a_{t}(p)=\frac{\sum_{i=0}^{p-1} x_{t-i}}{p},
$$

\footnotetext{
${ }^{1}$ Początek okresu badania dostosowano do momentu, w którym rozpoczął notowania „,najmłodszy” z porównywanych indeksów giełdowych, czyli indeks mWIG40.
} 
gdzie:

$p$ - długość okresu średniej kroczącej (liczba obserwacji),

$t$ - numer okresu,

$x_{t}-$ poziom indeksu giełdowego w czasie $t$.

Zgodnie z zasadami stosowania średniej ruchomej, sygnał kupna (sprzedaży) pojawia się wówczas, gdy średnia krótkookresowa (długookresowa) przekracza wartość średniej długookresowej (krótkookresowej). Niech $p$ będzie parametrem wygładzania dla średniej ruchomej krótkookresowej (,szybszej” średniej), $q$ - parametrem wygładzania dla średniej ruchomej długookresowej (,wolniejszej” średniej). Wówczas spełnienie jednego z poniższych warunków generuje [Gerov 2005, s. 9]:

$$
\begin{gathered}
\frac{\sum_{i=0}^{p-1} x_{t-i}}{p}>\frac{\sum_{i=0}^{q-1} x_{t-i}}{q}-\text { sygnał kupna, } \\
\frac{\sum_{i=0}^{p-1} x_{t-i}}{p}<\frac{\sum_{i=0}^{q-1} x_{t-i}}{q}-\text { sygnał sprzedaży. }
\end{gathered}
$$

Gdy wartość średniej krótkookresowej w niewielkim zakresie odchyli się od średniej długookresowej, to powstałe sygnały kupna lub sprzedaży odczytane za pomocą warunków (2) oraz (3) można uznać za słabe. W takiej sytuacji korzystne wydaje się zastosowanie procedury odfiltrowania słabych sygnałów kupna i sprzedaży. W niniejszym artykule zastosowano do tego celu tzw. band - pasmo wahań wokół długookresowej średniej kroczącej [Brock, Lakonishok i LeBaron 1992, s. 1738]. Zazwyczaj granicę tego pasma wyznacza się za pomocą arbitralnie przyjętego procentu wartości średniej długookresowej (np. 1\%). Sygnał kupna (sprzedaży) będzie generowany tylko wówczas, gdy wartość średniej krótkookresowej będzie wyższa (niższa) od wartości średniej długookresowej o więcej niż ustalony procent wartości „wolniejszej” średniej. Reguły generowania sygnałów zgodnych z przedstawioną tu zasadą opisują formuły (4) i (5).

Spełnienie jednego z poniższych warunków generuje [Gerov 2005, s. 11; Isakov i Hollistein 1999, s. 7-8]:

$$
\begin{aligned}
& \frac{\sum_{i=0}^{p-1} x_{t-i}}{p}>(1+b) \frac{\sum_{i=0}^{q-1} x_{t-i}}{q}-\text { sygnał kupna, } \\
& \frac{\sum_{i=0}^{p-1} x_{t-i}}{p}<(1-b) \frac{\sum_{i=0}^{q-1} x_{t-i}}{q}-\text { sygnał sprzedaży. }
\end{aligned}
$$

gdzie $b$ - ustalony procent „wolniejszej średniej”. 
Przedmiotem analizy w pracy będzie zbadanie, czy średnie warunkowe stopy zwrotu według strategii opartych na kupnie, sprzedaży oraz strategii mieszanej są istotnie różne od średniej stopy zwrotu obliczonej według strategii „kup i trzymaj” (obliczonej jako bezwarunkowa średnia stopa zwrotu z indeksu giełdowego w całym badanym okresie).

Do zweryfikowania istotności różnic średnich zastosowano testy statystyczne wyrażone formułami (6), (8), (9). Test istotności różnic średnich dla strategii partej na kupnie (sprzedaży) ma następującą postać (por. [Isakov i Hollistein 1999, s. 5]):

gdzie:

$$
t=\frac{\mu_{r}-\mu}{\sqrt{\frac{\sigma_{r}^{2}}{N_{r}}+\frac{\sigma^{2}}{N}},}
$$

$r=b$ dla strategii „,kupuj” oraz $p=s$ dla strategii „,sprzedaj”,

$\mu_{r}$ - warunkowa średnia stopa zwrotu dla strategii kupna (sprzedaży),

$\mu$ - średnia stopa zwrotu ze strategii „kup i trzymaj”,

$\sigma_{r}^{2}$ - warunkowa wariancja stóp zwrotu dla strategii kupna (sprzedaży),

$\sigma^{2}$ - wariancja dla stóp zwrotu obliczonych dla strategii „,kup i trzymaj”,

$N_{r}$ - liczba sygnałów kupna dla strategii kupna (sprzedaży),

$N$ - całkowita liczba obserwacji w badanym okresie (liczba sesji giełdowych).

Oprócz strategii opierających się na kupnie bądź sprzedaży, w artykule rozważono również strategię mieszaną, która uwzględnia także możliwość lokowania środków finansowych według stopy wolnej od ryzyka (np. w przypadku powstania słabych sygnałów neutralnych znajdujących się w paśmie wahań wokół średniej kroczącej długookresowej). Średnią warunkową stopę zwrotu z takiej strategii inwestycyjnej można obliczyć według wzoru [Isakov i Hollistein 1999, s. 7]:

$$
\mu=\frac{1}{T} \sum_{t=1}^{T}\left(r_{t} d_{1 t}+f_{t} d_{2 t}\right)
$$

gdzie:

$r_{t}-$ stopa zwrotu ceny waloru (indeksu) w momencie $t$,

$f_{t}$ - stopa wolna od ryzyka,

$d_{1 t}$ - zmienna o wartościach: 1 (sygnał kupna), -1 (sygnał sprzedaży) lub 0 (sygnał neutralny),

$d_{2 t}-$ zmienna o wartościach: 1 (sygnał neutralny) lub 0 (sygnał kupna lub sprzedaży).

Do zbadania istotności różnic stopy zwrotu ze strategii mieszanej i średniej stopy zwrotu ze strategii „kup i trzymaj” posłużono się statystyką testową (8) [Isakov i Hollistein 1999, s. 5]: 


$$
t=\frac{\mu_{m}-\mu}{\sqrt{\frac{\sigma_{m}^{2}}{N_{m}}+\frac{\sigma^{2}}{N}}},
$$

gdzie:

$\mu_{m}$ - warunkowa średnia stopa zwrotu dla strategii mieszanej (7),

$\mu$ - średnia stopa zwrotu według strategii „,kup i trzymaj”,

$\sigma^{2}$ - wariancja stóp ze zwrotu obliczonych dla strategii „kup i trzymaj”,

$\sigma_{m}^{2}$ - warunkowa wariancja stóp zwrotu dla strategii mieszanej,

$N_{m}$ - liczba wszystkich sygnałów w strategii mieszanej.

$N$ - całkowita liczba obserwacji w badanym okresie.

Stosowanie wzorów (6) oraz (8) do badania istotności różnic pomiędzy stopami zwrotu z inwestowania cyklicznego oraz strategii „,kup i trzymaj” wymaga spełnienia kilku założeń przez rozkłady stóp zwrotu, w tym założenia o normalności ich rozkładu. W praktyce to założenie nie zawsze bywa spełnione, a wynik testu istotności może być obciążony błędem. Aby zatem potwierdzić wyniki uzyskane w drodze tradycyjnych testów, przeprowadzono badania symulacyjne. Posłużono się w tym celu metodą bootstrapową, która polega na wielokrotnym wygenerowaniu wartości z tej samej próby. Zakłada się przy tym, że jeżeli próba losowa zawiera wszelkie niezbędne informacje o populacji, to przedmiotową próbę można traktować jako samą populację [Mielczarek 2007, s. 189]. Metoda bootstrapowa oparta jest na losowaniu ze zwracaniem, tzn. że obserwacje w nowo wylosowanej próbie mogą się powtarzać, a z kolei niektóre dane z próby wyjściowej mogą w ogóle nie wystąpić w próbie bootstrap. Metody bootstrapowe są często nieodzowne w przypadku niskiej podaży danych (np. krótkie szeregi czasowe) w sytuacji, gdy stosowane procedury statystyczne czy ekonometryczne wymagają dużej liczby obserwacji. Dzięki metodzie bootstrapowej uzyskano symulacyjne stopy zwrotu dla różnych systemów średnich kroczących, co pozwoliło na porównanie ich z odpowiednimi wartościami stóp zwrotu z oryginalnych szeregów czasowych. Wynikiem testu bootstrapowego jest więc odsetek przekroczeń „oryginalnych” warunkowych średnich przez ich odpowiedniki uzyskane poprzez symulację (tzw. bootstrapowe prawdopodobieństwo testowe).

Do replikacji stóp zwrotu indeksu giełdowego zastosowano procedurę przedstawioną przez W. Brocka, J. Lakonishoka i B. LeBarona [1992]. Polega ona na oszacowaniu parametrów teoretycznego modelu opisującego przebieg stóp zwrotu, a następnie obliczeniu reszt tego modelu. Niech więc równanie modelu opisującego kształtowanie się stopy zwrotu dane będzie wzorem:

$$
r_{t}=f\left(z_{t} ; \beta\right)+\varepsilon_{t},
$$


gdzie:

$r_{t}$ - stopa zwrotu,

$\mathrm{z}_{t}$ - zmienna objaśniająca,

$\beta$ - wektor parametrów modelu,

$\varepsilon_{t}-$ składnik losowy modelu.

Wektor ocen parametrów modelu (9) obliczony za pomocą odpowiedniego estymatora (np. estymatora KMNK) oznaczmy przez $\hat{\beta}$, wówczas reszty obliczamy na podstawie oszacowanego modelu regresji zgodnie z równaniem:

$$
\hat{\varepsilon}_{t}=f\left(z_{t} ; \hat{\beta}\right)-r_{t} .
$$

Reszty podlegają następnie repróbkowaniu i generowana jest próba bootstrapowa $\left(\varepsilon_{1}^{*}, \varepsilon_{2}^{*}, \ldots, \varepsilon_{n}^{*}\right)$, co umożliwia utworzenie wektora symulacyjnych stóp zwrotu $\left(r_{1}^{*}, r_{2}^{*}, \ldots, r_{n}^{*}\right)$ wyznaczanych zgodnie $\mathrm{z}$ równaniem:

$$
r_{t}^{*}=f\left(z_{t} ; \hat{\beta}\right)+\varepsilon_{t}^{*} .
$$

W artykule przeprowadzono 1000 symulacji stóp zwrotu dla każdego z trzech modeli: błądzenia losowego z dryfem, modelu autoregresji AR(1) oraz modelu AR(1) z efektem GARCH $(1,1)$. Obliczenia zostały przeprowadzone z wykorzystaniem programów komputerowych Excel i Gretl.

\section{Stopy zwrotu badanych strategii inwestycji}

Badania strategii inwestycyjnych prowadzono w odniesieniu do następujących indeksów giełdowych obliczanych dla spółek notowanych na GPW: WIG20, mWIG40 oraz sWIG80. Wykorzystując formuły (1)-(5), (7), obliczono przeciętne stopy zwrotu z inwestycji opartych na strategii kupna, sprzedaży i strategii mieszanej. Przy prezentacji wyników posłużono się następującym systemem oznaczeń dla stosowanych konfiguracji średnich kroczących: $(p, q, d)$, gdzie $p$ oznacza okres „szybszej” średniej ruchomej (w dniach), $q$ - okres wolniejszej średniej ruchomej (w dniach), $d$ - rozmiar pasma wahań wokół długookresowej średniej kroczącej (w \%) (por. [Gerov 2005, s. 11; Brock, Lakonishok i LeBaron 1992, s. 1738]). Gdy $p=1$, wówczas krótkookresowa średnia krocząca jest oryginalnym, wyjściowym szeregiem czasowym indeksu giełdowego. Przykładowo zestawienie $(2,200,1)$ oznacza, że sygnały kupna bądź sprzedaży są rozpoznawane na podstawie punktów przecięcia średnich kroczących 2-dniowej i 200-dniowej znajdujących się poza 1-procentowym pasmem wahań wokół długookresowej średniej. Analizę przeprowadzono dla wybranych konfiguracji $p \in\{1,2\}, q \in$ $\{5,10,30,50,150,200\}, d=\{0,1\}$. Wybór takich wartości parametrów $p, q$ i $d$ odpowiada najczęściej spotykanym długościom okresów średnich kroczących 
i rozmiarom pasma wahań filtrującego słabe sygnały w podobnych badaniach w literaturze przedmiotu [Brock, Lakonishok i LeBaron 1992, s. 1739; Isakov i Hollistein 1999, s. 6 i 9].

W tabeli 1 przedstawiono kształtowanie się liczby sygnałów kupna bądź sprzedaży w zależności od stosowanego systemu średnich kroczących i indeksu giełdowego. Pod liczbą sygnałów kupna i sprzedaży podano odsetek prawidłowo zidentyfikowanych sygnałów. Sygnał kupna (sprzedaży) można uznać za poprawny, jeśli poprzedza on dodatnią (ujemną) warunkową stopę zwrotu. Tabela 1 zawiera również łączną liczbę transakcji (kupna lub sprzedaży), przy czym jednej transakcji odpowiada seria następujących po sobie sygnałów kupna (sprzedaży).

Tabela 1. Liczby wykrytych sygnałów kupna i sprzedaży w zależności od systemu średnich kroczących

\begin{tabular}{|c|c|c|c|c|c|c|c|c|c|}
\hline \multirow{3}{*}{$\begin{array}{l}\text { Średnie } \\
\text { kroczące }\end{array}$} & \multicolumn{3}{|c|}{ WIG20 } & \multicolumn{3}{|c|}{ mWIG40 } & \multicolumn{3}{|c|}{ sWIG80 } \\
\hline & \multicolumn{2}{|c|}{ liczba sygnałów } & \multirow{2}{*}{$\begin{array}{c}\text { liczba } \\
\text { transak- } \\
\text { cji }\end{array}$} & \multicolumn{2}{|c|}{ liczba sygnałów } & \multirow{2}{*}{$\begin{array}{c}\text { liczba } \\
\text { transak- } \\
\text { cji } \\
\end{array}$} & \multicolumn{2}{|c|}{ liczba sygnałów } & \multirow{2}{*}{$\begin{array}{c}\text { liczba } \\
\text { transak- } \\
\text { cji } \\
\end{array}$} \\
\hline & $n_{b}$ & $n_{s}$ & & $n_{b}$ & $n_{s}$ & & $n_{b}$ & $n_{s}$ & \\
\hline$(1,5,0)$ & $\begin{array}{c}1783 \\
(48,57)\end{array}$ & $\begin{array}{c}1616 \\
(47,46)\end{array}$ & 885 & $\begin{array}{c}1898 \\
(57,11)\end{array}$ & $\begin{array}{c}1501 \\
(51,37)\end{array}$ & 732 & $\begin{array}{c}1880 \\
(62,13)\end{array}$ & $\begin{array}{c}1519 \\
(53,98)\end{array}$ & 680 \\
\hline$(1,5,1)$ & $\begin{array}{c}937 \\
(47,92)\end{array}$ & $\begin{array}{c}859 \\
(46,92)\end{array}$ & 708 & $\begin{array}{c}744 \\
(60,62)\end{array}$ & $\begin{array}{c}579 \\
(53,71)\end{array}$ & 490 & $\begin{array}{c}806 \\
(66,01)\end{array}$ & $\begin{array}{c}569 \\
(51,67)\end{array}$ & 483 \\
\hline$(1,10,0)$ & $\begin{array}{c}1799 \\
(49,25)\end{array}$ & $\begin{array}{c}1588 \\
(48,24)\end{array}$ & 565 & $\begin{array}{c}1952 \\
(56,46)\end{array}$ & $\begin{array}{c}1435 \\
(51,01)\end{array}$ & 460 & $\begin{array}{c}1840 \\
(60,33)\end{array}$ & $\begin{array}{c}1547 \\
(51,52)\end{array}$ & 456 \\
\hline$(1,10,1)$ & $\begin{array}{c}1262 \\
(48,73)\end{array}$ & $\begin{array}{c}1061 \\
(46,84)\end{array}$ & 539 & $\begin{array}{c}1227 \\
(57,95)\end{array}$ & $\begin{array}{c}817 \\
(53,12)\end{array}$ & 414 & $\begin{array}{c}1233 \\
(65,37)\end{array}$ & $\begin{array}{c}887 \\
(52,76)\end{array}$ & 360 \\
\hline$(1,30,0)$ & $\begin{array}{c}1869 \\
(49,39)\end{array}$ & $\begin{array}{c}1518 \\
(48,29)\end{array}$ & 295 & $\begin{array}{c}2010 \\
(55,52)\end{array}$ & $\begin{array}{c}1377 \\
(49,96)\end{array}$ & 225 & $\begin{array}{c}1822 \\
(61,09)\end{array}$ & $\begin{array}{c}1565 \\
(52,27)\end{array}$ & 183 \\
\hline$(1,30,1)$ & $\begin{array}{c}1260 \\
(48,65)\end{array}$ & $\begin{array}{c}1062 \\
(46,80)\end{array}$ & 539 & $\begin{array}{c}1656 \\
(55,98)\end{array}$ & $\begin{array}{c}1056 \\
(51,42)\end{array}$ & 230 & $\begin{array}{c}1526 \\
(62,98)\end{array}$ & $\begin{array}{c}1277 \\
(52,94)\end{array}$ & 191 \\
\hline$(1,50,0)$ & $\begin{array}{c}1957 \\
(50,03)\end{array}$ & $\begin{array}{c}1442 \\
(48,89)\end{array}$ & 236 & $\begin{array}{c}2022 \\
(56,08)\end{array}$ & $\begin{array}{c}1377 \\
(50,69)\end{array}$ & 150 & $\begin{array}{c}1829 \\
(61,35)\end{array}$ & $\begin{array}{c}1570 \\
(52,55)\end{array}$ & 121 \\
\hline$(1,50,1)$ & $\begin{array}{c}1722 \\
(49,65)\end{array}$ & $\begin{array}{c}1233 \\
(48,91)\end{array}$ & 225 & $\begin{array}{c}1779 \\
(56,89)\end{array}$ & $\begin{array}{c}1164 \\
(50,86)\end{array}$ & 163 & $\begin{array}{c}1648 \\
(62,38)\end{array}$ & $\begin{array}{c}1370 \\
(52,92)\end{array}$ & 126 \\
\hline$(1,100,0)$ & $\begin{array}{c}1979 \\
(50,88)\end{array}$ & $\begin{array}{c}1420 \\
(50,07)\end{array}$ & 124 & $\begin{array}{c}2051 \\
(55,83)\end{array}$ & $\begin{array}{c}1348 \\
(50,45)\end{array}$ & 105 & $\begin{array}{c}1949 \\
(60,95)\end{array}$ & $\begin{array}{c}1450 \\
(53,17)\end{array}$ & 74 \\
\hline$(1,100,1)$ & $\begin{array}{c}1865 \\
(50,72)\end{array}$ & $\begin{array}{c}1291 \\
(50,19)\end{array}$ & 124 & $\begin{array}{c}1879 \\
(56,31)\end{array}$ & $\begin{array}{c}1212 \\
(50,66)\end{array}$ & 104 & $\begin{array}{c}1830 \\
(60,98)\end{array}$ & $\begin{array}{c}1345 \\
(54,35)\end{array}$ & 74 \\
\hline$(1,150,0)$ & $\begin{array}{c}2068 \\
(50,29)\end{array}$ & $\begin{array}{c}1331 \\
(49,21)\end{array}$ & 148 & $\begin{array}{c}2164 \\
(55,87)\end{array}$ & $\begin{array}{c}1235 \\
(51,09)\end{array}$ & 91 & $\begin{array}{c}1989 \\
(60,73)\end{array}$ & $\begin{array}{c}1410 \\
(53,26)\end{array}$ & 52 \\
\hline$(1,150,1)$ & $\begin{array}{c}1939 \\
(50,39)\end{array}$ & $\begin{array}{c}1209 \\
(49,30)\end{array}$ & 139 & $\begin{array}{c}2039 \\
(56,30)\end{array}$ & $\begin{array}{c}1104 \\
(51,81)\end{array}$ & 76 & $\begin{array}{c}1892 \\
(60,73)\end{array}$ & $\begin{array}{c}1343 \\
(53,84)\end{array}$ & 46 \\
\hline
\end{tabular}


cd. tabeli 1

\begin{tabular}{|c|c|c|c|c|c|c|c|c|c|}
\hline \multirow{3}{*}{$\begin{array}{l}\text { Średnie } \\
\text { kroczące }\end{array}$} & \multicolumn{3}{|c|}{ WIG20 } & \multicolumn{3}{|c|}{ mWIG40 } & \multicolumn{3}{|c|}{ sWIG80 } \\
\hline & \multicolumn{2}{|c|}{ liczba sygnałów } & \multirow{2}{*}{$\begin{array}{c}\text { liczba } \\
\text { transak- } \\
\text { cji } \\
\end{array}$} & \multicolumn{2}{|c|}{ liczba sygnałów } & \multirow{2}{*}{$\begin{array}{c}\text { liczba } \\
\text { transak- } \\
\text { cji }\end{array}$} & \multicolumn{2}{|c|}{ liczba sygnałów } & \multirow{2}{*}{$\begin{array}{c}\text { liczba } \\
\text { transak- } \\
\text { cji } \\
\end{array}$} \\
\hline & $n_{b}$ & $n_{s}$ & & $n_{b}$ & $n_{s}$ & & $n_{b}$ & $n_{s}$ & \\
\hline$(1,200,0)$ & $\begin{array}{c}2076 \\
(51,30)\end{array}$ & $\begin{array}{c}1323 \\
(50,79)\end{array}$ & 72 & $\begin{array}{c}2173 \\
(55,59)\end{array}$ & $\begin{array}{c}1226 \\
(50,65)\end{array}$ & 73 & $\begin{array}{c}1976 \\
(60,17)\end{array}$ & $\begin{array}{c}1423 \\
(52,35)\end{array}$ & 40 \\
\hline$(1,200,1)$ & $\begin{array}{c}2001 \\
(51,12)\end{array}$ & $\begin{array}{c}1266 \\
(51,03)\end{array}$ & 83 & $\begin{array}{c}2067 \\
(56,07)\end{array}$ & $\begin{array}{c}1128 \\
(50,89)\end{array}$ & 72 & $\begin{array}{c}1906 \\
(60,23)\end{array}$ & $\begin{array}{c}1351 \\
(52,55)\end{array}$ & 44 \\
\hline$(2,200,0)$ & $\begin{array}{c}2067 \\
(51,19)\end{array}$ & $\begin{array}{c}1332 \\
(50,60)\end{array}$ & 54 & $\begin{array}{c}2159 \\
(55,58)\end{array}$ & $\begin{array}{c}1240 \\
(50,57)\end{array}$ & 49 & $\begin{array}{c}1962 \\
(60,14)\end{array}$ & $\begin{array}{c}1437 \\
(52,19)\end{array}$ & 31 \\
\hline$(2,200,1)$ & $\begin{array}{c}1996 \\
(50,90)\end{array}$ & $\begin{array}{c}1273 \\
(50,75)\end{array}$ & 57 & $\begin{array}{c}2057 \\
(55,96)\end{array}$ & $\begin{array}{c}1146 \\
(50,26)\end{array}$ & 54 & $\begin{array}{c}1901 \\
(60,28)\end{array}$ & $\begin{array}{c}1364 \\
(52,35)\end{array}$ & 35 \\
\hline
\end{tabular}

Źródło: obliczenia własne.

Z tabeli 1 wynika, że zwiększanie długości okresu „wolniejszej” długookresowej średniej kroczącej bez pasma wahań wokół tej średniej najczęściej sprzyja wzrostowi liczby sygnałów kupna i spadkowi liczby sygnałów sprzedaży dla wszystkich trzech indeksów giełdowych. W sytuacji zastosowania filtracji sygnałów w postaci 1-procentowego pasma wahań wokół długookresowej średniej dla porównywanych indeksów, wzrost długości okresu średniej kroczącej przeważnie zwiększa częstotliwość pojawiania się zarówno sygnałów kupna, jak i sprzedaży.

W tabeli 2 przedstawiono przeciętne stopy zwrotu z inwestycji opartych na strategiach kupna $\left(\mu_{b}\right)$, sprzedaży $\left(\mu_{s}\right)$ i strategii mieszanej $\left(\mu_{\mathrm{m}}\right)$ bez filtracji słabych sygnałów kupna i sprzedaży. W obliczeniach średniej stopy zwrotu dla strategii mieszanej $\left(\mu_{m}\right)$ jako stopę wolną od ryzyka (parametr $f_{t}$ we wzorze (7)) przyjęto oprocentowanie 26-tygodniowych bonów skarbowych. W nawiasach pod średnimi stopami zwrotu umieszczono wartości $p$-value odpowiadające wynikom testów istotności różnic warunkowych średnich stóp zwrotu i średniej stopy zwrotu strategii „kup i trzymaj” (wzory (6) i (8)).

$\mathrm{Z}$ tabeli 2 wynika, że wszystkie stosowane konfiguracje średnich kroczących dostarczały dodatnich średnich stóp zwrotu w zakresie stosowania strategii opartej na sygnałach kupna oraz strategii mieszanej. Posługując się wyłącznie strategią „,sprzedaj”, otrzymywano ujemne stopy zwrotu. Żadna z otrzymanych średnich stóp zwrotu dla indeksu WIG20 nie różniła się statystycznie istotnie od średniej stopy zwrotu ze strategii „kup i trzymaj”. W przypadku indeksu WIG40 uzyskano sześć rezultatów, które nie różniły się istotnie od tej średniej (po trzy dla strategii „kupuj” i dla strategii mieszanej) dla następujących zestawień średnich kroczących: $(1,150,0),(1,200,0),(2,200,0)$. Z kolei indeks sWIG80 dostarczył 
Tabela 2. Średnie stopy zwrotu indeksów giełdowych (w \%) dla trzech strategii inwestycyjnych przy zastosowaniu różnych systemów średnich kroczących bez pasma wahań wokół średniej długookresowej

\begin{tabular}{|c|c|c|c|c|c|c|c|c|c|}
\hline \multirow{2}{*}{$\begin{array}{l}\text { Średnia } \\
\text { krocząca }\end{array}$} & \multicolumn{3}{|c|}{ WIG20 } & \multicolumn{3}{|c|}{ mWIG40 } & \multicolumn{3}{|c|}{ sWIG80 } \\
\hline & $\mu_{b}$ & $\mu_{s}$ & $\mu_{m}$ & $\mu_{b}$ & $\mu_{s}$ & $\mu_{m}$ & $\mu_{b}$ & $\mu_{s}$ & $\mu_{m}$ \\
\hline$(1,5,0)$ & $\begin{array}{c}0,0533 \\
(0,5465)\end{array}$ & $\begin{array}{l}-0,0125 \\
(0,4864)\end{array}$ & $\begin{array}{c}0,0339 \\
(0,7965)\end{array}$ & $\begin{array}{c}0,1768 \\
(0,0001)\end{array}$ & $\begin{array}{l}-0,1358 \\
(0,0000)\end{array}$ & $\begin{array}{c}0,1587 \\
(0,0000)\end{array}$ & $\begin{array}{c}0,237 \\
(0,0000)\end{array}$ & $\begin{array}{l}-0,1603 \\
(0,0000)\end{array}$ & $\begin{array}{c}0,2028 \\
(0,0000)\end{array}$ \\
\hline$(1,10,0)$ & $\begin{array}{c}0,0441 \\
(0,6750)\end{array}$ & $\begin{array}{l}-0,0148 \\
(0,4631)\end{array}$ & $\begin{array}{c}0,0304 \\
(0,8627)\end{array}$ & $\begin{array}{c}0,1476 \\
(0,0018)\end{array}$ & $\begin{array}{c}-0,1181 \\
(0,0000)\end{array}$ & $\begin{array}{c}0,1351 \\
(0,0011)\end{array}$ & $\begin{array}{c}0,2091 \\
(0,0000)\end{array}$ & $\begin{array}{l}-0,1231 \\
(0,0000)\end{array}$ & $\begin{array}{c}0,1699 \\
(0,0002)\end{array}$ \\
\hline$(1,30,0)$ & $\begin{array}{c}0,0551 \\
(0,5173)\end{array}$ & $\begin{array}{c}-0,031 \\
(0,3030)\end{array}$ & $\begin{array}{c}0,0443 \\
(0,6094)\end{array}$ & $\begin{array}{c}0,1335 \\
(0,0061)\end{array}$ & $\begin{array}{l}-0,1088 \\
(0,0001)\end{array}$ & $\begin{array}{c}0,1234 \\
(0,0043)\end{array}$ & $\begin{array}{c}0,2196 \\
(0,0000)\end{array}$ & $\begin{array}{l}-0,1315 \\
(0,0000)\end{array}$ & $\begin{array}{c}0,1789 \\
(0,0000)\end{array}$ \\
\hline$(1,50,0)$ & $\begin{array}{c}0,0557 \\
(0,5018)\end{array}$ & $\begin{array}{l}-0,0238 \\
(0,3793)\end{array}$ & $\begin{array}{c}0,0422 \\
(0,6458)\end{array}$ & $\begin{array}{c}0,1364 \\
(0,0045)\end{array}$ & $\begin{array}{l}-0,1045 \\
(0,0002)\end{array}$ & $\begin{array}{c}0,1235 \\
(0,0042)\end{array}$ & $\begin{array}{c}0,2157 \\
(0,0000)\end{array}$ & $\begin{array}{l}-0,1225 \\
(0,0000)\end{array}$ & $\begin{array}{c}0,1727 \\
(0,0001)\end{array}$ \\
\hline$(1,100,0)$ & $\begin{array}{c}0,0776 \\
(0,2593)\end{array}$ & $\begin{array}{r}-0,0555 \\
(0,1433)\end{array}$ & $\begin{array}{c}0,0684 \\
(0,2746)\end{array}$ & $\begin{array}{c}0,1209 \\
(0,0167)\end{array}$ & $\begin{array}{c}-0,0862 \\
(0,0011)\end{array}$ & $\begin{array}{c}0,1071 \\
(0,0218)\end{array}$ & $\begin{array}{c}0,187 \\
(0,0002)\end{array}$ & $\begin{array}{c}-0,112 \\
(0,0000)\end{array}$ & \begin{tabular}{|c|}
0,1550 \\
$(0,0011)$
\end{tabular} \\
\hline$(1,150,0)$ & $\begin{array}{c}0,0396 \\
(0,7310)\end{array}$ & $\begin{array}{l}-0,0054 \\
(0,6031)\end{array}$ & $\begin{array}{c}0,0262 \\
(0,9437)\end{array}$ & $\begin{array}{c}0,1038 \\
(0,0551)\end{array}$ & $\begin{array}{c}-0,0752 \\
(0,0040)\end{array}$ & $\begin{array}{c}0,0934 \\
(0,0684)\end{array}$ & $\begin{array}{c}0,1751 \\
(0,0007)\end{array}$ & $\begin{array}{l}-0,1037 \\
(0,0000)\end{array}$ & $\begin{array}{c}0,1455 \\
(0,0034)\end{array}$ \\
\hline$(1,200,0)$ & $\begin{array}{c}0,0612 \\
(0,4246)\end{array}$ & $\begin{array}{l}-0,0394 \\
(0,2558)\end{array}$ & $\begin{array}{c}0,0527 \\
(0,4759)\end{array}$ & $\begin{array}{c}0,0906 \\
(0,1282)\end{array}$ & $\begin{array}{c}-0,053 \\
(0,0205)\end{array}$ & $\begin{array}{c}0,077 \\
(0,2071)\end{array}$ & $\begin{array}{c}0,1683 \\
(0,0015)\end{array}$ & $\begin{array}{l}-0,0916 \\
(0,0001)\end{array}$ & $\begin{array}{c}0,1362 \\
(0,0091)\end{array}$ \\
\hline$(2,200,0)$ & $\begin{array}{c}0,0527 \\
(0,5361)\end{array}$ & $\begin{array}{l}-0,0256 \\
(0,3748)\end{array}$ & $\begin{array}{c}0,0421 \\
(0,6492)\end{array}$ & $\begin{array}{c}0,0916 \\
(0,1211)\end{array}$ & $\begin{array}{c}-0,0532 \\
(0,0196)\end{array}$ & \begin{tabular}{c|c}
0,0776 \\
$(0,1998)$
\end{tabular} & $\begin{array}{c}0,1657 \\
(0,0020)\end{array}$ & $\begin{array}{l}-0,0856 \\
(0,0001)\end{array}$ & $\begin{array}{c}0,1318 \\
(0,0141)\end{array}$ \\
\hline
\end{tabular}

Źródło: obliczenia własne.

wyłącznie średnich stóp zwrotu, które istotnie różniły się od średniej stopy zwrotu ze strategii „kup i trzymaj” (dla strategii „kupuj” i strategii mieszanej były one statystycznie istotnie wyższe od tej średniej, natomiast dla strategii „sprzedaj” były istotnie niższe od tej średniej). Stosując strategię opartą na kupnie, najwyższe dochody można było uzyskać, lokując środki w spółki małe, zaś najniższe dochody przynosiły inwestycje w sektor dużych spółek: indeks sWIG80 miał najwyższe średnie stopy zwrotu dla wszystkich konfiguracji średnich kroczących, natomiast indeks WIG20 miał te stopy najniższe. Najwyższą przeciętną dzienną stopę zwrotu z indeksu sWIG80 dla strategii „kupuj” wynoszącą 0,237\% (tj. ok. 81,71\% w skali roku) dostarczył system średniej kroczącej $(1,5,0)$. Generalnie dla wszystkich porównywanych indeksów obserwowana jest następująca prawidłowość: im dłuższy okres „wolniejszej” średniej kroczącej tym niższa przeciętna stopa zwrotu ze strategii „kupuj”. Stosując strategię ,sprzedaj”, najniższe stopy zwrotu uzyskano z indeksu sWIG80, co w warunkach rynków spadkowych i możliwości stosowania krótkiej sprzedaży oznacza najwyższy dochód. Z kolei najniższych dochodów przy stosowaniu strategii sprzedaży można oczekiwać, inwestując w spółki duże: indeks WIG20 miał najwyższe średnie stopy zwrotu ze strategii „sprzedaj” dla wszystkich systemów średnich kroczących. Najwyższą bezwzględną przeciętną 
dzienną stopę zwrotu z indeksu sWIG80 dla strategii „sprzedaj” wynoszącą $0,1603 \%$ dostarczył system średniej kroczącej $(1,5,0)$. Wzrost długości okresu „wolniejszej” średniej kroczącej prowadzi zazwyczaj do wzrostu wartości warunkowej średniej stopy zwrotu ze strategii „sprzedaj” (ta zależność jest szczególnie widoczna dla indeksów mWIG40 i sWIG80).

W zakresie stosowania strategii mieszanej w dalszym ciągu najbardziej opłacalne były inwestycje w spółki małe (niezależnie od stosowanej konfiguracji średnich kroczących), natomiast najmniej opłacalne było inwestowanie w spółki duże. Najwyższą przeciętną dzienną stopę zwrotu ze stosowania strategii mieszanej wynoszącą 0,2028\% (tj. ok. 66,71\% w skali roku) dawała inwestycja w indeks sWIG80 zgodna systemem średnich kroczących $(1,5,0)$. Z kolei najniższą przeciętną dzienną stopę zwrotu strategii mieszanej wynoszącą 0,0304\% (tj. ok. 4,96\% w skali roku) dawała inwestycja w indeks WIG20 wykorzystująca system średnich kroczących $(1,10,0)$. Ujemną korelację pomiędzy wartościami stopy zwrotu i długością okresu „wolniejszej” średniej ruchomej obserwujemy szczególnie wyraźnie w przypadku indeksów mWIG40 i sWIG80.

Tabela 3. Średnie stopy zwrotu indeksów giełdowych (w \%) dla trzech strategii inwestycyjnych przy zastosowaniu różnych systemów średnich kroczących z 1-procentowym pasmem wahań wokół średniej długookresowej

\begin{tabular}{|c|c|c|c|c|c|c|c|c|c|}
\hline \multirow{2}{*}{$\begin{array}{l}\text { Średnie } \\
\text { kroczące }\end{array}$} & \multicolumn{3}{|c|}{ WIG 20} & \multicolumn{3}{|c|}{ mWIG40 } & \multicolumn{3}{|c|}{ sWIG80 } \\
\hline & $\mu_{b}$ & $\mu_{s}$ & $\mu_{m}$ & $\mu_{b}$ & $\mu_{s}$ & $\mu_{m}$ & $\mu_{b}$ & $\mu_{s}$ & $\mu_{m}$ \\
\hline$(1,5,1)$ & $\begin{array}{c}0,0651 \\
(0,5054)\end{array}$ & $\begin{array}{l}-0,0224 \\
(0,4827)\end{array}$ & \begin{tabular}{|c|}
0,0332 \\
$(0,7890)$
\end{tabular} & $\begin{array}{c}0,2950 \\
(0,0000)\end{array}$ & $\begin{array}{l}-0,3033 \\
(0,0000)\end{array}$ & $\begin{array}{c}0,1295 \\
(0,0006)\end{array}$ & $\begin{array}{c}0,3829 \\
(0,0000)\end{array}$ & $\begin{array}{l}-0,2255 \\
(0,0000)\end{array}$ & $\begin{array}{c}0,1417 \\
(0,0017)\end{array}$ \\
\hline$(1,10,1)$ & $\begin{array}{c}0,0708 \\
(0,3976)\end{array}$ & $\begin{array}{c}-0,0045 \\
(0,7535)\end{array}$ & $\begin{array}{c}0,0313 \\
(0,8360)\end{array}$ & $\begin{array}{c}0,1848 \\
(0,0003)\end{array}$ & $\begin{array}{l}-0,2230 \\
(0,0000)\end{array}$ & $\begin{array}{c}0,1288 \\
(0,0012)\end{array}$ & $\begin{array}{c}0,3262 \\
(0,0000)\end{array}$ & $\begin{array}{l}-0,2073 \\
(0,0000)\end{array}$ & $\begin{array}{c}0,1811 \\
(0,0000)\end{array}$ \\
\hline$(1,30,1)$ & $\begin{array}{c}0,0660 \\
(0,4469)\end{array}$ & $\begin{array}{c}-0,0063 \\
(0,7766)\end{array}$ & $\begin{array}{c}0,0289 \\
(0,8838)\end{array}$ & $\begin{array}{c}0,1546 \\
(0,0016)\end{array}$ & $\begin{array}{l}-0,1493 \\
(0,0000)\end{array}$ & $\begin{array}{c}0,1261 \\
(0,0024)\end{array}$ & $\begin{array}{c}0,2654 \\
(0,0000)\end{array}$ & $\begin{array}{l}-0,1518 \\
(0,0000)\end{array}$ & $\begin{array}{c}0,1799 \\
(0,0000)\end{array}$ \\
\hline$(1,50,1)$ & $\begin{array}{c}0,0596 \\
(0,4703)\end{array}$ & \begin{tabular}{|l|}
$-0,0421$ \\
$(0,2483)$
\end{tabular} & $\begin{array}{c}0,0481 \\
(0,5391)\end{array}$ & $\begin{array}{c}0,1526 \\
(0,0015)\end{array}$ & \begin{tabular}{|c|}
$-0,1193$ \\
$(0,0001)$
\end{tabular} & $\begin{array}{c}0,1236 \\
(0,0034)\end{array}$ & $\begin{array}{c}0,2379 \\
(0,0000)\end{array}$ & $\begin{array}{l}-0,1365 \\
(0,0000)\end{array}$ & $\begin{array}{c}0,1725 \\
(0,0001)\end{array}$ \\
\hline$(1,100,1)$ & \begin{tabular}{|c|}
0,0726 \\
$(0,3147)$
\end{tabular} & $\begin{array}{l}-0,0477 \\
(0,2024)\end{array}$ & $\begin{array}{c}0,0592 \\
(0,3775)\end{array}$ & \begin{tabular}{|c|}
0,1358 \\
$(0,0059)$
\end{tabular} & $\begin{array}{l}-0,0898 \\
(0,0013)\end{array}$ & $\begin{array}{c}0,1088 \\
(0,0173)\end{array}$ & $\begin{array}{c}0,1906 \\
(0,0002)\end{array}$ & $\begin{array}{l}-0,1397 \\
(0,0000)\end{array}$ & $\begin{array}{c}0,1592 \\
(0,0006)\end{array}$ \\
\hline$(1,150,1)$ & \begin{tabular}{|c|}
0,0524 \\
$(0,5481)$
\end{tabular} & $\begin{array}{l}-0,0132 \\
(0,5220)\end{array}$ & $\begin{array}{c}0,0361 \\
(0,7517)\end{array}$ & $\begin{array}{c}0,1081 \\
(0,0444)\end{array}$ & $\begin{array}{l}-0,0971 \\
(0,0010)\end{array}$ & $\begin{array}{c}0,0981 \\
(0,0446)\end{array}$ & $\begin{array}{c}0,1853 \\
(0,0003)\end{array}$ & $\begin{array}{l}-0,1206 \\
(0,0000)\end{array}$ & $\begin{array}{c}0,1516 \\
(0,0015)\end{array}$ \\
\hline$(1,200,1)$ & $\begin{array}{c}0,0591 \\
(0,4548)\end{array}$ & $\begin{array}{l}-0,0439 \\
(0,2312)\end{array}$ & $\begin{array}{c}0,0519 \\
(0,4841)\end{array}$ & $\begin{array}{c}0,0998 \\
(0,0764)\end{array}$ & $\begin{array}{l}-0,0685 \\
(0,0088)\end{array}$ & $\begin{array}{c}0,0849 \\
(0,1214)\end{array}$ & $\begin{array}{c}0,1696 \\
(0,0015)\end{array}$ & $\begin{array}{l}-0,0993 \\
(0,0000)\end{array}$ & $\begin{array}{c}0,1353 \\
(0,0096)\end{array}$ \\
\hline$(2,200,1)$ & \begin{tabular}{|c|}
0,0487 \\
$(0,5967)$
\end{tabular} & $\begin{array}{l}-0,0210 \\
(0,4288)\end{array}$ & $\begin{array}{c}0,0372 \\
(0,7343)\end{array}$ & $\begin{array}{c}0,0946 \\
(0,1062)\end{array}$ & $\begin{array}{l}-0,0442 \\
(0,0406)\end{array}$ & $\begin{array}{c}0,0736 \\
(0,2489)\end{array}$ & $\begin{array}{c}0,1692 \\
(0,0016)\end{array}$ & $\begin{array}{l}-0,0874 \\
(0,0001)\end{array}$ & $\begin{array}{c}0,1303 \\
(0,0157)\end{array}$ \\
\hline
\end{tabular}

Źródło: obliczenia własne. 
W tabeli 3 przedstawiono przeciętne stopy zwrotu z inwestycji opartych na strategiach kupna $\left(\mu_{b}\right)$, sprzedaży $\left(\mu_{s}\right)$ i strategii mieszanej $\left(\mu_{\mathrm{m}}\right)$ z uwzględnieniem procesu filtracji słabych sygnałów kupna i sprzedaży.

Stosując filtrację sygnałów kupna i sprzedaży poprzez jednoprocentowe pasmo wahań wokół wolniejszej średniej kroczącej dla wszystkich porównywanych indeksów i wszystkich systemów średnich kroczących, uzyskano dodatnie stopy zwrotu dla strategii „kupuj”, strategii mieszanej oraz ujemne stopy zwrotu dla strategii „sprzedaj”. Struktura średnich warunkowych stóp zwrotów według rodzajów indeksów i systemów średnich kroczących, które istotnie różniły się (bądź nie różniły się) od średniej stopy zwrotu ze strategii „kup i trzymaj” jest podobna do tej z tabeli 2, a mianowicie warunkowe średnie stopy zwrotu z indeksu WIG20 nie różniły się statystycznie istotnie od średniej stopy zwrotu ze strategii „kup i trzymaj". Natomiast w przypadku pozostałych indeksów stosowanie strategii mieszanej i strategii „kupuj” (,sprzedaj”) najczęściej generowało stopy zwrotu przeciętnie istotnie wyższe (niższe) od średniej stopy zwrotu ze strategii „kup i trzymaj”"2. Zastosowanie 1-procentowego pasma wahań wokół „wolniejszej” średniej kroczącej nie zmieniło w zasadzie relacji pomiędzy spółkami małymi, średnimi i dużymi pod względem zyskowności inwestycji w te grupy spółek: w dalszym ciągu niezależnie od stosowanej strategii inwestycyjnej najbardziej dochodowe jest inwestowanie w indeks sWIG80, a najmniej zyskowne okazało się inwestowanie w indeks WIG20. Warto zwrócić uwagę, że filtracja sygnałów kupna i sprzedaży dla prawie wszystkich konfiguracji średnich kroczących spowodowała zwiększenie przeciętnych stóp zwrotu przede wszystkim z indeksów mWIG40 i sWIG80 w przypadku strategii „kupuj” oraz jednocześnie spowodowała zmniejszenie stóp zwrotu z tych indeksów w warunkach strategii „sprzedaj”. Dla pozostałych przypadków wpływ filtracji na przeciętne stopy zwrotu nie jest już tak jednoznaczny. Stosując strategię „kupuj” z jednoprocentowym pasmem wahań, najwyższą przeciętną dzienną stopę zwrotu wynoszącą 0,3829\% (tj. ok. $162,5 \%$ w skali roku) można było osiągnąć, inwestując w indeks sWIG80. Kierując się strategią „sprzedaj” i stosując system średnich kroczących $(1,5,1)$, inwestor osiągnie największy dochód, gdy będzie inwestował w indeks mWIG40 (średnia bezwzględna dzienna stopa zwrotu z tego indeksu wyniosła $0,3033 \%$ ). Z kolei strategia mieszana okazała się najbardziej zyskowna dla inwestora stosującego system średnich $(1,10,1)$ w odniesieniu do spółek małych (średnia dzienna stopa zwrotu wyniosła ok. 0,1811\%).

${ }^{2}$ Wyjątek stanowi indeks WIG20 z systemem średnich kroczących $(1,200,1),(2,200,1)$. 


\section{Wyniki testów bootstrapowych}

Wyniki badań wykazały, że rozkłady empiryczne stóp zwrotu indeksu giełdowego cechują się asymetrią, są leptokurtyczne, wykazują istotną autokorelację rzędu pierwszego bądź wyższych rzędów i w konsekwencji mogą być niezgodne z rozkładem normalnym. W związku z powyższym wyniki testów istotności różnic warunkowych stóp zwrotu i stopy zwrotu ze strategii „kup i trzymaj” mogą być obciążone błędem ${ }^{3}$. Aby zatem potwierdzić rezultaty uzyskane w drodze tradycyjnych testów, przeprowadzono badania symulacyjne, których celem jest weryfikacja wyników uzyskanych w tabelach 2 i 3. Samą procedurę symulacji szczegółowo przedstawiono w punkcie 2.

W niniejszych badaniach przeprowadzono 1000 symulacji stóp zwrotu dla każdego z trzech modeli:

- błądzenia losowego z dryfem,

- modelu autoregresji AR(1) (por. [Isakov i Hollistein 1999, s. 12]),

$$
r_{t}=\alpha_{0}+\alpha_{1} r_{t-1}+\varepsilon_{t},
$$

- modelu AR(1) z efektem GARCH (1,1) (por. [Isakov i Hollistein 1999, s. 12; Kosiorowski 2012, s. 177]):

$$
\sigma_{t}^{2}=\alpha_{0}+\alpha_{1} \varepsilon_{t-1}^{2}+\beta_{1} \sigma_{t-1}^{2} .
$$

Symulacje przeprowadzono dla następujących wybranych konfiguracji średnich kroczących $(1,5,0),(1,50,0),(1,100,0),(1,150,0)$ oraz $(1,200,0)$. Wyniki obejmujące symulacyjne prawdopodobieństwa bootstrapowego podano w tabeli 4.

Jeżeli wartość symulacyjnego prawdopodobieństwa testowego jest mniejsza od 0,05 lub wyższa od 0,95 , to wskazuje, że replikowane stopy zwrotu dostarczają istotnie niższych lub wyższych warunkowych średnich stóp zwrotu od ich odpowiedników otrzymanych na podstawie oryginalnego szeregu czasowego stóp zwrotu (por. [Osler 1998, s. 21]). Oznacza to, że modele teoretyczne błędnie replikują empiryczne stopy zwrotu dla poszczególnych strategii i nie pozawalają na wyjaśnienie różnic pomiędzy warunkowymi charakterystykami liczbowymi empirycznych stóp zwrotu i charakterystykami liczbowymi strategii „kup i trzymaj”.

Analizując wyniki w tabeli 4 można stwierdzić, że stosunkowo dużo istotnych statystycznie wyników uzyskano dla stóp zwrotu z indeksu giełdowego mWIG 40 oraz sWIG 80 . W większości przypadków otrzymane rezultaty poprzez symulacje bootstrapowe są zgodne z wynikami tradycyjnych testów istotności (por. tabele 2 i 3), chociaż w przypadku niektórych strategii inwestycyjnych

${ }^{3}$ Stosowanie wzorów (6) i (8) wymaga spełnienia założenia m.in. o normalności rozkładu zmiennych losowych. 
zwłaszcza przy zastosowaniu „,wolniejszej” średniej kroczącej o dłuższym okresie można wskazać niezgodność w zakresie prawdopodobieństwa testowego uzyskanego w klasycznym teście oraz symulacyjnego $p$-value. Przykładowo stosując system średnich kroczących $(1,200,0)$ w okresach generowania sygnałów kupna, uzyskuje się warunkową stopę zwrotu z indeksu mWIG40 równą 0,0906\%, która nieistotnie różni się od stopy zwrotu ze strategii „kup i trzymaj” (prawdopodobieństwo testowe wynosi 0,128220). Z drugiej strony bootstrapowe prawdopodobieństwo testowe uzyskane dla modeli błądzenia losowego i modelu autoregresji AR(1) wskazuje, że co najwyżej 0,2\% symulacji dostarczyło średnich warunkowych stóp zwrotu przekraczających średnie warunkowe stopy zwrotu uzyskane z oryginalnych szeregów czasowych. Oznacza to, że założenie co do normalności rozkładu stóp zwrotu mogło mieć wpływ na wynik statystycznej istotności różnic w klasycznym teście istotności.

Tabela 4. Bootstrapowe prawdopodobieństwa testowe w symulacjach stóp zwrotu indeksów giełdowych

\begin{tabular}{|c|c|c|c|c|c|c|c|c|c|c|}
\hline \multirow{2}{*}{$\begin{array}{l}\text { Średnie } \\
\text { kroczące }\end{array}$} & \multirow{2}{*}{ Model } & \multicolumn{3}{|c|}{ WIG20 } & \multicolumn{3}{|c|}{ mWIG40 } & \multicolumn{3}{|c|}{ sWIG80 } \\
\hline & & $\mu_{b}$ & $\mu_{s}$ & $\mu_{m}$ & $\mu_{b}$ & $\mu_{s}$ & $\mu_{m}$ & $\mu_{b}$ & $\mu_{s}$ & $\mu_{m}$ \\
\hline \multirow{3}{*}{$(1,5,0)$} & RW & 0,112 & 0,633 & 0,110 & 0,000 & 1,000 & 0,000 & 0,000 & 1,000 & 0,000 \\
\hline & $\operatorname{AR}(1)$ & 0,283 & 0,539 & 0,183 & 0,000 & 1,000 & 0,000 & 0,000 & 1,000 & 0,000 \\
\hline & $\operatorname{GARCH}(1,1)$ & 0,128 & 0,694 & 0,033 & 0,000 & 0,994 & 0,000 & 0,000 & 1,000 & 0,000 \\
\hline \multirow{3}{*}{$(1,50,0)$} & RW & 0,150 & 0,672 & 0,122 & 0,000 & 1,000 & 0,000 & 0,000 & 1,000 & 0,000 \\
\hline & $\mathrm{AR}(1)$ & 0,244 & 0,656 & 0,210 & 0,000 & 1,000 & 0,000 & 0,000 & 0,967 & 0,000 \\
\hline & $\operatorname{GARCH}(1,1)$ & 0,128 & 0,772 & 0,078 & 0,067 & 0,822 & 0,044 & 0,000 & 1,000 & 0,000 \\
\hline \multirow{3}{*}{$(1,100,0)$} & RW & 0,194 & 0,844 & 0,161 & 0,000 & 1,000 & 0,000 & 0,000 & 1,000 & 0,000 \\
\hline & $\mathrm{AR}(1)$ & 0,306 & 0,822 & 0,213 & 0,000 & 1,000 & 0,001 & 0,000 & 0,922 & 0,000 \\
\hline & $\operatorname{GARCH}(1,1)$ & 0,039 & 0,944 & 0,028 & 0,217 & 0,678 & 0,167 & 0,000 & 1,000 & 0,000 \\
\hline \multirow{3}{*}{$(1,150,0)$} & RW & 0,217 & 0,561 & 0,222 & 0,000 & 1,000 & 0,000 & 0,001 & 1,000 & 0,000 \\
\hline & $\mathrm{AR}(1)$ & 0,317 & 0,561 & 0,222 & 0,001 & 1,000 & 0,001 & 0,003 & 0,918 & 0,001 \\
\hline & $\operatorname{GARCH}(1,1)$ & 0,228 & 0,594 & 0,106 & 0,411 & 0,461 & 0,439 & 0,012 & 1,000 & 0,013 \\
\hline \multirow{3}{*}{$(1,200,0)$} & RW & 0,239 & 0,744 & 0,289 & 0,000 & 1,000 & 0,000 & 0,001 & 1,000 & 0,004 \\
\hline & $\mathrm{AR}(1)$ & 0,433 & 0,722 & 0,267 & 0,002 & 1,000 & 0,003 & 0,004 & 0,856 & 0,002 \\
\hline & $\operatorname{GARCH}(1,1)$ & 0,083 & 0,867 & 0,156 & 0,350 & 0,011 & 0,833 & 0,015 & 0,992 & 0,008 \\
\hline
\end{tabular}

Źródło: obliczenia własne.

Największy odsetek symulacji, które dostarczały warunkowych stóp zwrotu nieróżniących się istotnie od warunkowych stóp zwrotu obliczonych z „oryginalnego" indeksu WIG40, uzyskano, posługując się modelem autoregresji AR(1) 
z efektem GARCH $(1,1)$. Stosując modele błądzenia losowego i modele autoregresji AR(1), uzyskuje się znacznie częściej symulacje dostarczające przeciętnych warunkowych stóp zwrotu istotnie różnych od stóp obliczonych z oryginalnych szeregów czasowych.

Bootstrapowe prawdopodobieństwa testowe bliskie zeru dla strategii wykorzystującej sygnały kupna i strategii mieszanej nie pozwalają na wyjaśnienie wysokich przeciętnych wartości średnich warunkowych stóp zwrotu indeksu mWIG40 dla obu tych strategii. Z kolej prawdopodobieństwa testowe bliskie $1 \mathrm{w}$ przypadku strategii inwestycyjnej wykorzystującej spadki stóp zwrotu indeksu mWIG40 nie dają możliwości wyjaśnienia niskich przeciętnych stóp zwrotu dla strategii opartej na sygnałach sprzedaży. Podobne rezultaty uzyskano dla indeksu giełdowego małych spółek w odniesieniu do porównywanych strategii (tabela 4).

W przypadku indeksu WIG20 (tabela 4) symulacyjne prawdopodobieństwa testowe wskazywały z reguły na dobrą replikację stóp zwrotu (frakcja symulacji, które generowały warunkowe średnie stopy zwrotu przekraczające „oryginalne” stopy zwrotu była zazwyczaj wyższa od 5\% i niższa od 95\%), co znajduje potwierdzenie w wynikach klasycznych testów istotności (tabela 2). Można więc potwierdzić, że stosując strategie inwestycyjne wykorzystujące sygnały kupna, sprzedaży, czy strategię mieszaną inwestor giełdowy inwestujący w duże spółki nie zarobi istotnie więcej niż zarobiłby, stosując strategię „kup i trzymaj”. Wskazują na to rezultaty uzyskane dla wszystkich trzech modeli teoretycznych replikujących stopy zwrotu.

\section{Podsumowanie}

Z przedstawionych analiz wynika, że niezależnie od stosowanej strategii inwestycyjnej, najbardziej opłaca się inwestować w sektor małych spółek, natomiast najmniej opłacalne okazują się inwestycje w duże spółki. Zastosowanie filtracji słabszych sygnałów kupna i sprzedaży w postaci 1-procentowego „korytarza” wahań wokół długookresowej średniej kroczącej także potwierdza ten wniosek. Uwzględnienie w prowadzonej analizie kosztów transakcji, reprezentowanych przez prowizję dla inwestorów instytucjonalnych i indywidualnych [Jajuga 2008], umożliwiło porównanie efektywności strategii mieszanej stosowanej dla wybranych systemów średniej kroczącej w odniesieniu do indeksów WIG20, mWIG40 i sWIG80. Wyniki tego badania potwierdziły, że najbardziej efektywne są inwestycje w indeks sWIG80, zaś najmniej efektywne - w indeks WIG20. Ze wstępnych analiz empirycznych stóp zwrotu z porównywanych indeksów wynika m.in., że wykazują one autokorelację i nie mają rozkładu normalnego, w związku z czym 
wyniki klasycznych testów istotności mogą być obciążone błędami. W związku z tym wyniki klasycznych testów statystycznych uzupełniono o analizę symulacyjną. Wyniki badań symulacyjnych potwierdziły również, że na ogół istniały istotne różnice pomiędzy warunkowymi średnimi stopami zwrotu uzyskanymi w drodze symulacji oraz warunkowymi stopami zwrotu z oryginalnych indeksów sWIG80 i mWIG40. W przypadku indeksu WIG20 symulacyjne prawdopodobieństwa testowe wskazywały przeważnie brak istotnych różnic pomiędzy warunkowymi stopami zwrotu otrzymanymi z danych symulacyjnych oraz z danych pochodzących z oryginalnego szeregu czasowego stóp zwrotu. Wyniki symulacji bootstrapowych zazwyczaj znajdowały potwierdzenie w wynikach klasycznych testów istotności.

\section{Literatura}

Brock W., Lakonishok J., LeBaron B. [1992], Simple Technical Trading Rules and the Stochastic Properties of Stock Returns, ,Journal of Finance”, vol. 47.

Czekała M. [1997], Analiza fundamentalna i techniczna, Wydawnictwo Akademii Ekonomicznej im. Oskara Langego we Wrocławiu, Wrocław.

Gencay R. [1996], Non-linear Prediction of Security Returns with Moving Average Rules, „Journal of Forecasting”, vol. 15.

Gerov M.I. [2005], The Predictive Power and Economic Effectiveness of Trading Rules Strategies: Application of VMA $(p, q, r)$ and TRB $(p, r, d)$ Conditional Models to Canadian Equity Market, Concordia University, Montreal.

Isakov D., Hollistein M. [1999], Application of Simple Technical Trading Rules to Swiss Stock Prices: Is It Profitable?, „Financial Markets and Portfolio Management”, vol. 13, nr 1.

Jajuga K., Jajuga T. [2008], Inwestycje. Instrumenty finansowe, aktywa niefinansowe, ryzyko finansowe, inżynieria finansowa, Wydawnictwo Naukowe PWN, Warszawa.

Kosiorowski D. [2012], Statystyczne funkcje głębi w odpornej analizie ekonomicznej, „Zeszyty Naukowe Uniwersytetu Ekonomicznego w Krakowie”, Seria specjalna: Monografie, nr 208.

Mielczarek B. [2007], Metody próbkowania w symulacji Monte Carlo, Prace Naukowe Instytutu Organizacji i Zarządzania Politechniki Wrocławskiej, nr 83, Wrocław.

Murphy J.J. [1999], Analiza techniczna rynków finansowych, Wydawnictwo Finansowe WIG-Press, Warszawa.

Osler C.L. [1998], Identifying Noise Traders: the Head-and-Shoulders Pattern in U.S. Equities, Federal Reserve Bank of New York, New York.

Pring M.J. [1998], Podstawy analizy technicznej, WIG-Press, Warszawa. 


\section{An Application of the Bootstrap Method for Testing the Profitability of Selected Investment Strategies on the Warsaw Stock Exchange}

The paper presents selected technical trading rules on the Polish stock market along with an estimate of the market's profitability. Technical trading rules allow one to forecast changes to a stock price and identify buy and sell signals on Warsaw Stock Exchange. To do so, variable-length moving averages are applied to the main Polish stock indexes. To evaluate the economic effectiveness of the technical trading rules, $t$-statistics are used for testing the significance of the differences between average returns and the bootstrap techniques.

Keywords: technical analysis, moving average, bootstrap method, GARCH model. 